\title{
Construção da imagem institucional do Poder Judiciário - uma análise baseada nas campanhas publicitárias do Conselho Nacional de Justiça
}

\author{
Institutional image building for the Judiciary Power - an analysis based on the advertising \\ campaigns of the National Council of Justice
}

João Felipe Rammelt Sauerbronn ${ }^{1}$

Marluce Dantas de Freitas Lodi

\begin{abstract}
Resumo
Com a criação do Conselho Nacional de Justiça (CNJ) em 2004, passou a existir no Judiciário um espaço para reflexão e orientação das práticas e do posicionamento institucional deste Poder. Dentro do escopo do CNJ encontra-se o planejamento das ações promotoras da mudança da imagem do Judiciário, que inclui campanhas publicitárias lançadas desde 2008 pelo CNJ com o intuito de promover uma nova maneira como o Judiciário interage com a sociedade. Este artigo tem por objetivo apresentar como o CNJ utiliza peças publicitárias para construir a imagem institucional do Judiciário diante dos cidadãos. Para tanto, as peças publicitárias oficiais lançadas pelo CNJ foram analisadas com base no método de análise do discurso publicitário proposto por Pinto (2002), que sugere uma abordagem interpretativa, fundamentada na análise de três funções do discurso publicitário: mostração; interação; e sedução. Por meio da análise das peças foi possível oferecer uma interpretação a respeito da proposta de construção de imagem institucional em questão. Fica clara a utilização de dois discursos publicitários que conferem uma base à construção da imagem do Judiciário pelo CNJ: o discurso operacional, que se refere fundamentalmente à divulgação de métodos de prestação jurisdicional que aumentem a celeridade do Judiciário; e o discurso social, que coloca o Judiciário como condutor da discussão de temas controversos, como a punição à violência contra a mulher, a aplicação de penas alternativas e a ressocialização de egressos do sistema prisional, o que claramente evidencia a nova postura do Judiciário.
\end{abstract}

Palavras-chave: Administração pública. Administração do Judiciário. Comunicação do Judiciário. Discurso publicitário.

\begin{abstract}
Since the National Council of Justice (CNJ) was created, in 2004, there's a space in the Judiciary for reflection and guidance with regard to the practices and institutional positioning of this Power. Within the scope of CNJ, one finds out the planning of actions promoting a change in the Judiciary image, which includes advertising campaigns, launched from 2008 by CNJ, in order to promote a new way how the Judiciary interacts with society. This paper aims to present how CNJ uses advertising pieces to build the Judiciary institutional image before the citizens. For this, the official advertising pieces launched by CNJ were analyzed having as a basis the advertising discourse analysis method proposed by Pinto (2002), who suggests an interpretive approach, grounded on the analysis of three functions of the advertising discourse: showing; interaction; and seduction. By analyzing the advertising pieces, it was possible to offer an interpretation of the proposal of institutional image construction concerned. The use of two advertising discourses supporting the Judiciary image construction by $\mathrm{CNJ}$ becomes apparent: the operational discourse, which mainly refers to the promotion of
\end{abstract}

Artigo submetido em 30 de novembro de 2011 e aceito para publicação em 02 de outubro de 2012.

${ }^{1}$ Professor do PPGA/Unigranrio; Doutor em Administração pela EBAPE/FGV. Endereço: Rua da Lapa, 86 - 9ำ andar, CEP 20021-180, Rio de Janeiro-RJ, Brasil. E-mail: joao.sauerbronn@unigranrio.br

${ }^{2}$ Professora do Centro Universitário Carioca; Mestre em Adminsitração pela Unigranrio. Endereço: Rua da Lapa, 86 - 9ํandar, CEP 20021-180, Rio de Janeiro-RJ, Brasil. E-mail: marluce.lodi@gmail.com 
jurisdictional proceeding methods to increase the speed of the Judiciary; and the social discourse, which attributes to the Judiciary a key role in the discussion of controversial themes, such as punishment to violence against women, the application of alternative sentencing, and the ressocialization of former prisoners, something which clearly shows the new Judiciary attitude.

Keywords: Public administration. Judiciary administration. Communication of the Judiciary. Advertising discourse.

\section{Introdução}

O Conselho Nacional de Justiça (CNJ) foi criado em 31 de dezembro de 2004 e instalado em junho de 2005, quando então assumiu o papel de condutor das reformas que a sociedade vem exigindo do Poder Judiciário (BADIN, 2009). Trata-se de um órgão do Poder Judiciário que visa ao aperfeiçoamento do serviço público de prestação jurisdicional e que surgiu no escopo das transformações introduzidas pela Emenda Constitucional n. ${ }^{\circ}$ 45/2004. Desde então, o CNJ passou a ser o órgão voltado à reformulação de quadros e meios no Judiciário, sobretudo no que diz respeito ao controle e à transparência administrativa e processual. Composto por quinze conselheiros com mandato de dois anos, o CNJ passou a estabelecer metas a serem cumpridas pelos tribunais e a punir os membros do Judiciário que não as cumprissem. O CNJ tem planejado ações que promovem aumento da transparência da prestação jurisdicional e cobrado de juízes e serventuários atuações mais condizentes com as necessidades da população.

Como uma das claras preocupações do CNJ está relacionada à mudança da imagem do Judiciário, desde 2008 o órgão vem lançando campanhas publicitárias com esse intuito. Temas como celeridade, justiça e paz social, tão presentes nos discursos dos componentes do Judiciário, passaram a ganhar corpo em campanhas amplamente divulgadas na mídia em geral. O CNJ deu início a um novo movimento de posicionamento institucional deste poder. Ao desenvolver campanhas de comunicação com a sociedade, o CNJ alterou a maneira como o Poder Judiciário interage com os cidadãos e deixou clara sua preocupação com a construção de sua imagem institucional.

O objetivo no presente trabalho é apresentar uma compreensão a respeito de como o CNJ utiliza peças publicitárias para construir a imagem institucional do Judiciário diante dos cidadãos. Para tanto, foram analisadas as formas de comunicação utilizadas pelo órgão em suas peças publicitárias oficiais e, por meio da análise dessas peças, foi possível oferecer uma interpretação a respeito da proposta de construção de imagem institucional deliberadamente promovida. Fica clara a utilização de dois discursos publicitários que dão base à construção da imagem do Judiciário pelo CNJ: o discurso operacional, relacionado fundamentalmente à divulgação de métodos de prestação jurisdicional que aumentem a celeridade do Judiciário; e o discurso social, que coloca o Judiciário como condutor da discussão de temas controversos, como a punição à violência contra a mulher, a aplicação de penas alternativas e a ressocialização de egressos do sistema prisional; o que claramente evidencia sua nova postura.

Para que se entenda melhor como se deu o processo de criação do CNJ, retoma-se no artigo a discussão da reforma do Estado brasileiro a partir de 1995 e da reforma do Judiciário que ocorreu dez anos depois. Os caminhos desta reforma ajudam a compor a compreensão do papel do CNJ como responsável pela construção da imagem institucional do Poder Judiciário.

$\mathrm{Na}$ fundamentação teórica desse trabalho, os conceitos de "marketing institucional", "propaganda" e "imagem" são abordados levando-se em conta a discussão pertinente ao Poder Judiciário. Importantes para a administração pública, a adoção dessas ferramentas pode aumentar a eficácia das ações do Poder Judiciário, principalmente no que diz respeito à construção de sua imagem perante a sociedade.

Para orientar o estudo das peças publicitárias e do processo de construção da imagem institucional do Judiciário, foi utilizado o método de análise do discurso publicitário proposto por Pinto (2002). Esse método sugere uma abordagem interpretativa. Ao longo da seção de procedimentos metodológicos, as funções de 
mostração (construção do universo do discurso), de interação (estabelecimento de vínculos socioculturais) e de sedução (distribuição de afetos positivos e negativos) são apresentadas e discutidas para que sirvam de base à compreensão das formas de construção de discursos publicitários por meio das peças do CNJ. Foram analisadas oito peças publicitárias oficiais lançadas pelo CNJ no período de 2008 a 2010, com o objetivo de investigar as formas de comunicação utilizadas pelo Judiciário.

A relevância deste trabalho reside no fato de tratar de tema importante para a administração pública, e para o Poder Judiciário em especial, que é a comunicação institucional e as formas de interação entre setor público e sociedade. O CNJ é um órgão que representa uma nova forma de administração deste poder e, ao conhecer a forma como ele constrói sua imagem diante dos cidadãos, pode ser possível identificar e propor melhorias nas diversas formas de comunicação com o público e, entre outras ações, aumentar a eficácia de futuras peças publicitárias.

\section{Reforma do Estado Brasileiro de 1995}

Ao longo dos anos 1980 e 1990, o papel do Estado na economia e na sociedade foi rediscutido. O debate centralizou-se na melhoria da gestão pública e na definição de formas de atuação do Estado que fossem condizentes com a nova realidade econômica mundial (DINIZ, 2002). A partir daí, teve início um período de transformação na administração pública dos países centrais em direção a uma administração pública gerencial. A reforma gerencial foi uma resposta à demanda por maior eficiência na oferta de serviços para o consumo coletivo e ao processo de globalização e serviu para legitimar o Estado Social (BRESSER PEREIRA, 2001).

Segundo Rezende (2004), a reforma administrativa brasileira ocorrida na segunda metade dos anos 1990 teve como objetivos: a alteração do papel do Estado, a redução de custos e a definição de um novo desenho institucional. Dessa forma, pretendeu-se mudar o modelo burocrático da administração pública para um modelo orientado pelo desempenho. Os administradores públicos deveriam tornar-se mais autônomos e responsáveis e as agências executoras dos serviços sociais mais descentralizadas (BRESSER PEREIRA, 2001). Conforme menciona Abrucio (1998), o modelo gerencial implantado no Brasil buscou responder com maior agilidade e eficiência os anseios da sociedade, insatisfeita com os serviços recebidos do setor público.

Em 1995, no escopo da reforma do Estado brasileiro, foi criado o Ministério da Administração Federal e da Reforma do Estado (MARE), responsável pelo desenvolvimento do Plano Diretor da Reforma do Aparelho do Estado (PDRAE), que tinha como proposta a criação de organizações sociais, entidades privadas com autonomia e flexibilidade de gestão e descentralização da prestação de serviços públicos. A partir desse ponto abriu-se espaço para a privatização de órgãos públicos e para a introdução de mudanças no modelo de administração pública.

A implantação da reforma administrativa deu-se com a tentativa de incorporação de um modelo gerencial focado em eficiência, qualidade no atendimento ao cidadão, accountability e transparência, que teve origem no New Public Management (NPM) (BRESSER PEREIRA, 2000). Ao se preocupar com o serviço que presta ao cidadão, o Estado incorporou ferramentas de gestão típicas das organizações empresariais e passou a se interessar também pela definição de sua imagem institucional.

\section{Reforma do Judiciário e Criação do Conselho Nacional de Justiça}

Desde a criação do MARE em 1995 havia uma proposta de reforma do Poder Judiciário. Entretanto, segundo Bresser Pereira (1996), houve forte resistência, àquele tempo, por parte de juristas e magistrados a qualquer proposta deste tipo. Somente em dezembro de 2004, depois de mais de uma década de tramitação, foi aprovada a Emenda Constitucional n. ${ }^{\circ}$ 45/2004, que tratava da reforma do Judiciário. Com esta emenda 
tinha-se como objetivo aumentar a capilaridade do sistema judicial brasileiro, tornando-o mais acessível e ágil e viabilizando a solução institucional de conflitos que, devido ao tempo excessivo e à distância da justiça, terminavam por serem resolvidos na arena privada (RIBEIRO, 2008).

Uma das soluções oferecidas pela reforma do Poder Judiciário no sentido de tornar a justiça mais célere e mais efetiva foi a criação do CNJ. Mesmo tendo sua composição aparentemente mais próxima às questões doutrinárias da aplicação do direito, o CNJ foi aparelhado para tratar das questões administrativas e financeiras dos tribunais. A sua criação trouxe a atenção da administração pública para o Judiciário no sentido de se dar mais ênfase à gestão (área meio) dentro dos tribunais. Visto que sempre houve resistência por parte dos magistrados à instalação de um órgão de planejamento, coordenação e controle do Judiciário, a criação do CNJ pode ser considerada a grande inovação advinda desta reforma (VIEIRA e PINHEIRO, 2008). Observando o Poder Judiciário por suas atribuições de Poder de Estado e de órgão público prestador de serviços, como propõe Sadek (2004), percebe-se que, por mais que sua atuação política provoque discussões e controvérsias, é a sua atuação como serviço público que se encontrava (e ainda se encontra) realmente em crise e precisava ser resolvida prioritariamente.

O CNJ passou a estabelecer metas a serem cumpridas pelos tribunais e a punir os membros do Judiciário que não as cumprissem, em uma atuação impregnada da essência do gerencialismo que caracterizou a reforma do Estado brasileiro. Para Badin (2009), o CNJ veio servir como local institucional onde são depositadas as aspirações sociais de um Poder Judiciário mais transparente, mais célere e mais responsável, que garantisse o direito exigido e inerente ao cidadão. A criação do $\mathrm{CNJ}$ representou um impulso em direção a práticas administrativas mais modernas e eficientes (BADIN, 2009), assumindo, dessa forma, o papel de condutor das reformas que a sociedade vem exigindo do Judiciário.

Segundo Nalini (2006), até a criação do CNJ, o Judiciário não possuía um espaço onde pudesse pensar o seu futuro e se questionar sobre sua insuficiência em atender à demanda da população por justiça. Coube ao CNJ promover encontros nacionais dos tribunais de justiça e conduzir a elaboração do Plano Estratégico do Poder Judiciário, propondo um conjunto de ações que visam ao aperfeiçoamento e à efetividade da prestação jurisdicional. Para Chaer, Azevedo e Bonifácio (2009) foi em virtude de inovações como esta que teve início a aproximação dos tribunais à prestação de serviço público, direcionando a democratização do acesso à justiça.

Como colocam Vieira e Pinheiro (2008), o CNJ tem três atribuições: i) planejamento e publicidade do Judiciário, cujo objetivo é modificar a pouca tradição deste poder na elaboração de dados consolidados sobre as suas atividades e na utilização destes para planejar e melhorar a prestação do serviço jurisdicional à sociedade; ii) fiscalização dos deveres funcionais de magistrados e servidores, para tratar do controle disciplinar dos magistrados, servidores e serventuários da justiça, de modo a possibilitar o bom desenvolvimento da atividade jurisdicional; e iii) controle da gestão do Judiciário, baseado no processo regulatório que tem como objetivos o cumprimento da lei e das instruções e a execução de suas atribuições, bem como atos e o rendimento de cada servidor público.

Dentro das ações de planejamento e publicidade do Poder Judiciário, deve-se destacar que o CNJ passou a ser o responsável por conduzir a apresentação e o posicionamento do Judiciário na sociedade. Essa interface com a sociedade ganhou especial destaque dentro do processo de reforma e ainda sofre resistência por parte de alguns setores do Judiciário brasileiro.

\section{Marketing do Setor Público e Imagem Institucional do Poder Judiciário}

No início dos anos 1970, Kotler e Levy (ver: Kotler e Levy, 1969; Kotler, 1972) propuseram a ampliação do conceito de marketing e, por consequência, a incorporação de seu uso por organizações que não visam ao lucro. Mesmo enfrentando algumas manifestações de insatisfação, como a apresentada por Luck (1969), a academia de marketing ampliou seus domínios e passou a discutir o marketing das organizações do setor público. Em paralelo a essa trajetória da academia, a aproximação da administração pública a perspectivas 
gerencialistas possibilitou o desenvolvimento efetivo de práticas de marketing em organizações públicas. Dessa forma, muitas contribuições de acadêmicos de marketing passaram a focar esse tipo de organização ver: Wilkie e Gardner (1974) e Dyer e Shimp (1977) e as propostas de uso da pesquisa de marketing como suporte a políticas públicas; Walsh (1994) e Laing (2003) e as perspectivas da gestão de serviços públicos baseadas em marketing de serviços; Ewing e Caruana (1999) e a abordagem de marketing interno no setor público, por exemplo.

Para Walsh (1994), a natureza do marketing do setor público está relacionada a três dimensões: i) o crescimento do consumerismo; ii) a adoção do marketing estratégico; e iii) o uso de atividades de promoção. Uma vez implantada uma orientação para o setor público focada no gerencialismo, não seria estranho que organizações públicas passassem a se preocupar com o gerenciamento de imagem como ferramenta para o alcance de seus objetivos.

No período entre os anos 1950 e 1970 surgiram os primeiros trabalhos a respeito da gestão da imagem organizacional (BALMER, 2009). Tais estudos aprofundaram a importância da percepção a respeito da organização, mas não trataram de diferenciar a organização como transmissora de imagens e stakeholders como receptores dessas imagens. Assim, o marketing institucional passou a tratar das múltiplas relações de troca com múltiplos grupos e redes de stakeholders, tanto internos quanto externos à organização. A dimensão temporal de tais relacionamentos também se mostrou importante, na medida em que o foco do marketing institucional se estende desde os relacionamentos atuais entre organização e seus stakeholders, até os relacionamentos passados e as possíveis relações futuras.

Atividades de comunicação podem ser utilizadas como forma de fortalecer ideias e imagens e manter, formar, desenvolver, consolidar, ou mudar o conceito público a respeito de uma organização (POYARES, 1998). Assim, a orientação pelo marketing institucional é de investimento na imagem da organização, e mesmo as instituições públicas que não visam ao lucro podem fazer uso do marketing institucional lançando mão de um processo de conscientização de ideias e atitudes, com o objetivo de alcançar um determinado comportamento social (KOTLER, 1972; 2008).

Dentro do Poder Judiciário coube ao CNJ provocar a reflexão a respeito de sua imagem institucional. Muito embora a justiça brasileira venha passando por inúmeras mudanças, para a sociedade não está claro que algo venha acontecendo. Uma vez que o CNJ tem a clara intenção de mostrar ao cidadão como está sendo gerido o Poder Judiciário e quer ser reconhecido como parte representativa de uma nova forma de administração pública, precisa, então, fazer uso de técnicas capazes de sensibilizar seu público. A pressão de movimentos pela melhoria dos serviços públicos forçou a aproximação do Judiciário com o marketing institucional e trouxe a este poder uma nova visão a respeito de si diante de seus públicos.

Embora seja crescente o procura da população pelos serviços jurisdicionais, ainda há dificuldade em compreender o real papel do Poder Judiciário. A comunicação entre este e a sociedade ainda é vista como precária, carente de ajustes e de mediações competentes e efetivas. No entanto, é dever do Judiciário dar informações sobre seus atos como pressuposto democrático pelo princípio da publicidade, legitimando assim a instituição perante a opinião pública.

Segundo Sadek (2009), a principal marca da justiça brasileira ainda é a lentidão. Essa deficiência, por si só, prejudica enormemente a garantia de direitos e a solução de conflitos. Uma das formas de solucionar essa deficiência foi a criação de campanhas incentivando a participação da sociedade na solução de conflitos por meio do diálogo, com vistas a garantir mais celeridade e efetividade à justiça. Assim, foi resolvido um dos problemas do Poder Judiciário, que sofre com o excesso de demanda, bem como foram apresentadas soluções para a sociedade que não passaram despercebidas em campanhas de comunicação.

A atividade jurisdicional tem o dever de satisfazer totalmente os anseios do cidadão, no sentido de ser justa, completa, efetiva e rápida. Porém, não é suficiente somente a execução destas ações, é necessário que elas sejam percebidas pelo cidadão. Por isso, torna-se necessário usar técnicas de marketing institucional e comunicação com o público para que o efetivo trabalho jurisdicional seja de fato notado pelo usuário, seja 
reposicionando sua imagem ou promovendo a conscientização do cidadão sobre os seus direitos e deveres e o funcionamento da justiça.

\section{Propaganda e o Discurso Publicitário}

Uma valiosa ferramenta do marketing institucional é a propaganda, entendida como a mensagem divulgada em veículos de grande penetração e patrocinada por um anunciante, cuja finalidade é criar ou reforçar imagens ou preferências na mente do receptor (aquele que recebe a mensagem publicitária), predispondo-o favoravelmente em relação ao produto, serviço ou instituição patrocinadora (KOTLER, 2000). A função da propaganda é criar, mudar ou reforçar atitudes mentais que vão influir no comportamento das pessoas (KOTLER, 2000).

A propaganda pode ser utilizada para estruturar a imagem desejada para uma organização. É uma das ferramentas de comunicação mais penetrantes e permite alcançar frequentemente grandes públicos (KOTLER, 2008). Pode-se dizer que uma imagem pública é formada quando um indivíduo ou organização interage com outro indivíduo ou organização, desempenhando papéis sociais. Dessa forma, ambos se abastecem de informações estabelecendo uma situação inicial e formando uma imagem prévia um do outro.

A publicidade tem o poder de influenciar a criação de novos estilos, comportamentos, padrões de vida ideal, novos conceitos, valores, despertar desejos, ou frustrações, ao mesmo tempo em que oferece soluções para elas, interferindo culturalmente e socialmente na vida das pessoas, explorando o universo dos desejos e desempenhando manutenção da imagem institucional de uma organização, fundamental para a sua credibilidade (CARVALHO, 2004).

Uma das claras preocupações do $\mathrm{CNJ}$ está relacionada à mudança da imagem do Judiciário. O órgão realizou uma série de esforços de comunicação baseada em propagandas com o objetivo de modificar ou construir uma nova imagem para o Poder Judiciário. Desde a sua criação, entre outras ações, vem lançando campanhas publicitárias com esse intuito. Temas como celeridade, justiça e paz social, tão presentes nos discursos dos componentes do Judiciário, passaram a ganhar corpo em campanhas amplamente divulgadas nas mídias.

Segundo Tavares (2006), quando se investiga o discurso publicitário, quase sempre se menciona manipulação, o que pode ser aplicado em discursos políticos, jurídicos, jornalísticos, e acadêmicos. O discurso publicitário usa recursos estilísticos e argumentativos da linguagem cotidiana, esta própria voltada para informar e manipular combinando elementos persuasivos. Possui um contexto envolvente e sedutor com características que mostram o universo social e é fundado sobre as retóricas emocional, racional e institucional (TAVARES, 2006).

Direcionado para a construção de relações entre o emissor e o receptor, o discurso publicitário tem o intuito de construir uma determinada imagem do que se quer mostrar. A imagem de um emissor está em constante construção, e a concepção que se tem desse emissor pode mudar de acordo com suas ações (PINTO, 2002).

Mediante a identificação de valores e anseios do seu público, é possível ao interlocutor adaptar seu discurso ao seu público alvo a fim de construir ou manter uma imagem confiável de si mesmo ou de quem ele deseja representar. Essa imagem precisa estar de acordo com a cultura e os valores de quem ele deseja convencer. De acordo com Tavares (2006), a mensagem publicitária é constituída de linguagem verbal e outros sistemas semióticos (como as imagens). Essa mensagem que se deseja transmitir necessita não somente ser compreendida, mas também seduzir o receptor, portanto os elementos verbais e não verbais mencionados precisam ser estrategicamente selecionados e trabalhados.

Segundo Carvalho (2009), o discurso publicitário é um dos instrumentos de controle social que utilizam a linguagem da sedução com o objetivo de produzir o consumo. Sendo assim, um anúncio não se limita apenas 
a mostrar o produto, é também forma de representação social e permite a exploração dos códigos verbais e não verbais expostos nas propagandas.

O objetivo neste trabalho, como já foi apresentado, é compreender como o CNJ constrói sua imagem institucional ante os cidadãos, quais técnicas foram usadas com as funções presentes nos discursos publicitários das propagandas deste órgão. Para tanto, é necessário que sejam apresentados os procedimentos metodológicos, o que é feito a seguir.

\section{Procedimentos Metodológicos}

Tendo em vista o objetivo do presente trabalho de compreender como o CNJ constrói a imagem institucional do Judiciário perante os cidadãos por meio da análise das peças publicitárias lançadas por este órgão, foi necessária a utilização de método apropriado. Após observação e avaliação de métodos utilizados na área de comunicação social, o método de análise do discurso publicitário proposto por Pinto (2002) mostrou-se a opção mais apropriada. Tal método ofereceu condições de acesso objetivo aos dados presentes nas peças publicitárias, assim como uma proposta bastante sólida de orientação para sua análise.

Para Pinto (2002), a mensagem publicitária possui três funções básicas, chamadas pelo autor de "modos de dizer", que são: mostração (construção do universo do discurso), interação (estabelecimento de vínculos socioculturais) e sedução (distribuição de afetos positivos e negativos). Para o autor, o método de análise do discurso publicitário serve para descrever, explicitar e avaliar os processos de produção, circulação e recepção dos suportes textuais, a fim de compreender seus significados no contexto social (PINTO, 2002).

De acordo com Pinto (2002), na função de mostração (construção do universo do discurso), tanto os textos verbais quanto as imagens apresentam características necessárias para que emissor e receptor da mensagem estabeleçam relações entre elas de acordo com o universo em questão. Essa função consiste em designar e descrever as coisas ou pessoas de que se fala, estabelecendo relações entre elas e localizando-as no tempo e no espaço, sempre em relação ao que o receptor supostamente conheceria deste universo em pauta.

$\mathrm{Na}$ função de interação (estabelecimento de vínculos socioculturais), o emissor procura reproduzir determinada hierarquia de acordo com sua estratégia de persuasão, usando frases imperativas, assertivas ou interrogativas nos textos verbais. Para Pinto (2002, p. 67): “[...] o problema a ser resolvido aqui é reproduzir as hierarquias sociais reconhecidas no interior da instituição em que o processo de comunicação se dá". Para atingir o mesmo efeito com as imagens, o emissor usa recursos que denotem posição de poder mediante um modo de olhar ou posição dominante que define a interpelação e o estabelecimento de relações de poder com o receptor, na tentativa de agir sobre ele ou sobre o mundo por seu intermédio com base nos vínculos socioculturais.

Já a função de sedução (distribuição de afetos positivos e negativos) consiste em marcar as pessoas, coisas e acontecimentos referidos com valores positivos e negativos e ainda em demonstrar uma reação afetiva favorável ou desfavorável a eles. Essa função faz uso do reforço de valores hegemônicos em questão de forma não explícita. Tanto na mensagem verbal quanto no uso das imagens sugere-se uma reação afetiva favorável ou desfavorável a eles, através de acontecimentos também de acordo com a estratégia de persuasão. Assim, texto e imagem são complementares.

A operação do método de análise do discurso publicitário compreendeu três etapas para cada uma das peças de publicidade obtidas pelos autores diretamente da assessoria de comunicação do CNJ. A primeira etapa focou a leitura e análise do texto. Assim, cada peça teve seu texto lido e cada uma das funções (mostração, interação e sedução) foi identificada em seu conteúdo. Na segunda etapa, processo semelhante repetiu-se com foco no conteúdo imagético. Imagens, cores, sombras e desenhos foram interpretados tendo em mente as funções da mensagem publicitária. A terceira etapa fechou o processo de análise individual das peças com o objetivo de gerar uma interpretação completa do discurso publicitário de cada uma delas. A construção da 
peça como um todo, com seus textos e imagens, foi discutida e exposta pelos pesquisadores como fonte de interpretação. Ao fim, na quarta etapa, todas as campanhas foram colocadas lado a lado em um painel e foram feitas comparações, pelos pesquisadores, entre as peças de forma mais próxima. Como resultado, foi possível identificar os componentes utilizados na construção da imagem institucional do Judiciário pelo CNJ e também duas categorias de discurso publicitário.

Quadro 1

Etapas do processo de análise das peças publicitárias

\begin{tabular}{|c|c|}
\hline Etapa & Atividade \\
\hline Leitura do texto & Interpretação do texto \\
\hline Observação do conteúdo imagético & Interpretação das imagens \\
\hline Consolidação (texto e imagem) & Interpretação do discurso publicitário \\
\hline Comparação de peças publicitárias & Contraste entre discursos publicitários \\
\hline
\end{tabular}

Fonte: elaborado pelos autores.

As peças publicitárias oficiais do CNJ constituem o corpus de dados desta pesquisa e, com base no acervo do órgão, foram levantadas todas as campanhas publicitárias e todas as propagandas veiculadas no período entre 2004, ano da criação do CNJ, e 2010. Foram encontradas oito peças, produzidas entre os anos de 2008 e 2010, englobando cinco temas de campanhas definidas pelo CNJ, a saber: Programa Começar de Novo, Movimento pela Conciliação, Meta 2, Justiça Criminal e Lei Maria da Penha. A análise das peças publicitárias, apresentada na seção de análise de dados, segue a ordem cronológica de cada campanha. Para fins de apresentação das análises, o corpus de dados do estudo delimitado foi dividido em ciclos de campanhas, pois cada uma delas poderia ter mais de uma peça publicitária em virtude dos diferentes períodos de veiculação. As peças são apresentadas como figuras numeradas de 1 a 8 ao longo da seção de análise dos dados. Devido a limitações de espaço e tamanho de arquivo, as imagens foram reproduzidas com baixa definição.

\section{Análise dos Dados}

Sendo todas as campanhas definidas pelo CNJ e produzidas em espaço de tempo relativamente curto (entre 2008 e 2010), componentes do discurso publicitário foram comuns a todas as peças e manifestaram funções semelhantes. Temas como celeridade da justiça, paz social, transparência e cidadania são recorrentes e nortearam a construção da imagem do Judiciário pelo CNJ. Com o discurso publicitário presente nas propagandas, o CNJ mostra que a participação da sociedade é muito importante para a realização dos objetivos do Poder Judiciário e que, sem a aderência da sociedade às ideias tratadas pelo CNJ, torna-se impossível modificar a imagem deste poder.

São apresentas a seguir as análises das peças publicitárias e a proposta de categorização destas. Dadas as limitações de tamanho e espaço do formato de artigo, a matriz analítica que consolida os dados, desenvolvida na quarta etapa do processo de análise das peças publicitárias, é reproduzida no Quadro 3, ao fim dessa seção. 


\section{Programa Começar de Novo}

Na primeira peça desse programa, o CNJ procura deixar manifesto que é ele quem está patrocinando o projeto e deseja o engajamento da sociedade. Dessa forma, constrói por meio de seu discurso publicitário a imagem de um órgão que trata de questões de relevância social. Por intermédio dessa campanha é definido um horizonte comum entre o Judiciário e o cidadão, com utilização de imagens verbais e não verbais que tratam de ressocialização, inclusão social, cidadania, diminuição da criminalidade, equidade, participação da sociedade nas ações do Poder Público.

Figura 1

\section{Peça publicitária do Programa Começar de Novo - 2008}

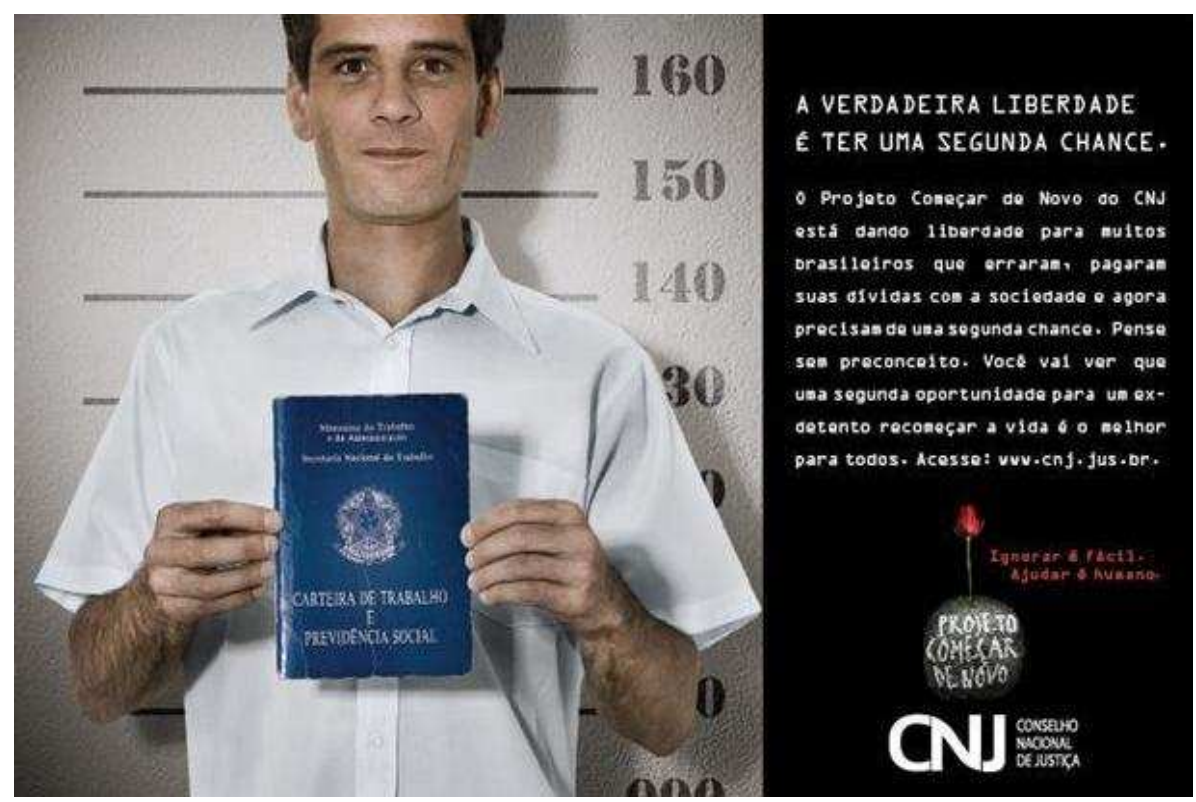

Fonte: Conselho Nacional de Justiça, 2011.

\section{Figura 2}

Peça publicitária do Programa Começar de Novo - 2009

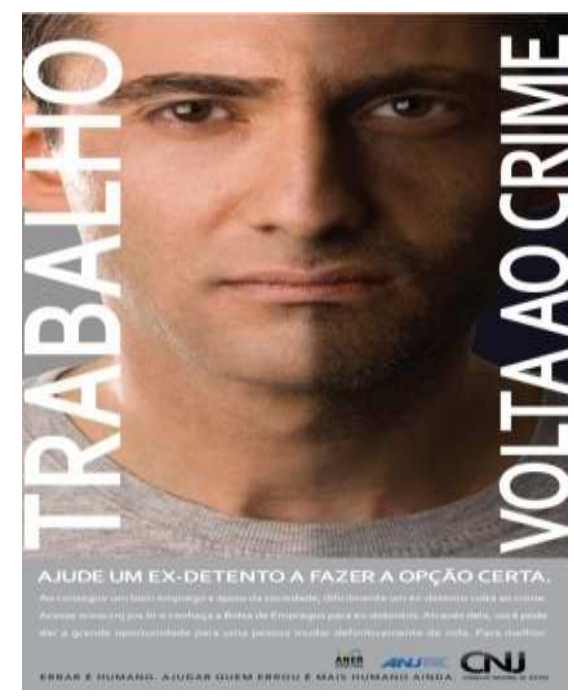

Fonte: Conselho Nacional de Justiça, 2011. 
A campanha é composta por duas peças publicitárias (mostradas nas figuras 1 e 2) que utilizam discursos muito semelhantes. A função de mostração aparece no texto das duas por meio da descrição do programa ao público. A proposta do programa é explicitada pela defesa do trabalho como solução para a ressocialização do indivíduo e também pelo contraste entre trabalho e crime. A função de mostração está presente, ainda, na Figura 1, nas imagens da carteira de trabalho, da régua utilizada na identificação de criminosos, da bola de ferro (que representa a prisão e da flor que nasce dessa bola de ferro - elas reforçam o contraste de situações, também presente no rosto metade claro, metade escuro do indivíduo (Figura 2). A função de interação tem espaço na convocação feita pelo CNJ em "Pense sem preconceito", além do uso de expressões performativas como "você vai ver" e "é o melhor para todos", que reforçam os aspectos de interação e hierarquização e o propósito das ações do CNJ cujo suporte da sociedade é necessário. A interação está presente, na peça reproduzida na Figura 1, na identificação com o homem que segura a carteira de trabalho e gera cumplicidade com o receptor. O olhar do indivíduo retratado na peça reproduzida na Figura 2 também procura gerar interação com o receptor e compartilhar com ele o problema. A função de sedução apresenta-se no texto por intermédio de palavras como "liberdade", "humano", "ajuda" e "trabalho" (afetos positivos) e "erro" e "crime" (afetos negativos), sendo reforçada por imagens contrastantes como a flor que nasce da bola de ferro.

A utilização de palavras como "trabalho", "emprego" e "apoio" em ambas as peças visa estabelecer vínculos entre o CNJ e a sociedade. Fica clara a intenção de transformar a imagem do Poder Judiciário, que sempre foi sinônimo de punição e prisão, na imagem de um órgão voltado para equidade, justiça, proteção, liberdade, ou seja, para ações em prol do cidadão, algo que nem sempre foi claro para a sociedade. Além das preocupações sociais do CNJ, que estão claras em ambas as peças dessa campanha, também pode ser observado em segundo plano um objetivo operacional para a justiça. Na medida em que indivíduos que saem da cadeia conseguem se restabelecer de forma honesta e a reincidência no crime diminui, a demanda por processos em varas criminais também tende a cair. Dessa forma, haveria um impacto sobre a operação dos tribunais, que passariam a receber menos processos e teriam diminuição na taxa de crescimento de seus estoques de processos.

\section{Movimento pela Conciliação}

A campanha do Movimento pela Conciliação foi composta por três peças publicitárias. Na campanha de 2008 (Figura 3), a função de mostração apresenta a conciliação como forma de resolver conflitos, reforçada pela imagem de traços simples que representa uma audiência de conciliação. Na campanha de 2009 (Figura 4), a função de mostração refere-se à mudança na justiça e tem como suporte as cores nacionais em letras grandes, enquanto, na campanha de 2010 (Figura 5), o aperto de mãos dá suporte à ideia de entendimento e pacificação social. A função de interação aparece nos textos que tratam da abertura da justiça à sociedade, nas imagens de contato entre as partes (apertos de mãos retratados nas peças publicitárias reproduzidas nas figuras 3 e 5) e nas cores verde e amarelo (Figura 4). A função de sedução está presente em afetos positivos em termos relacionados a rapidez, simplicidade, entendimento e ganho e em imagens de situações amistosas e harmoniosas. 
Figura 3

Peça publicitária do Movimento pela Conciliação - 2008

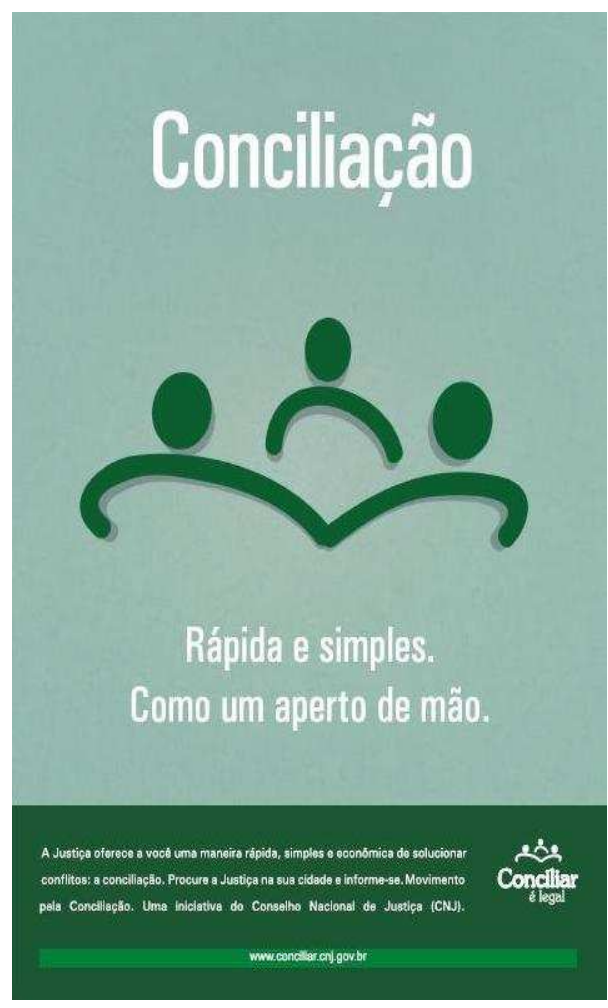

Fonte: Conselho Nacional de Justiça, 2011

Figura 4

Peça publicitária do Movimento pela Conciliação - 2009

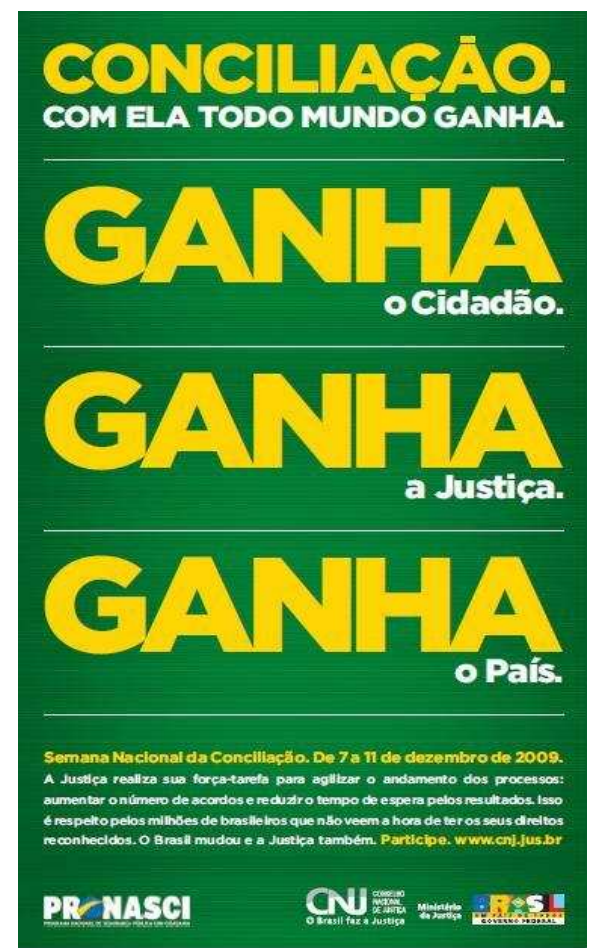

Fonte: Conselho Nacional de Justiça, 2011 


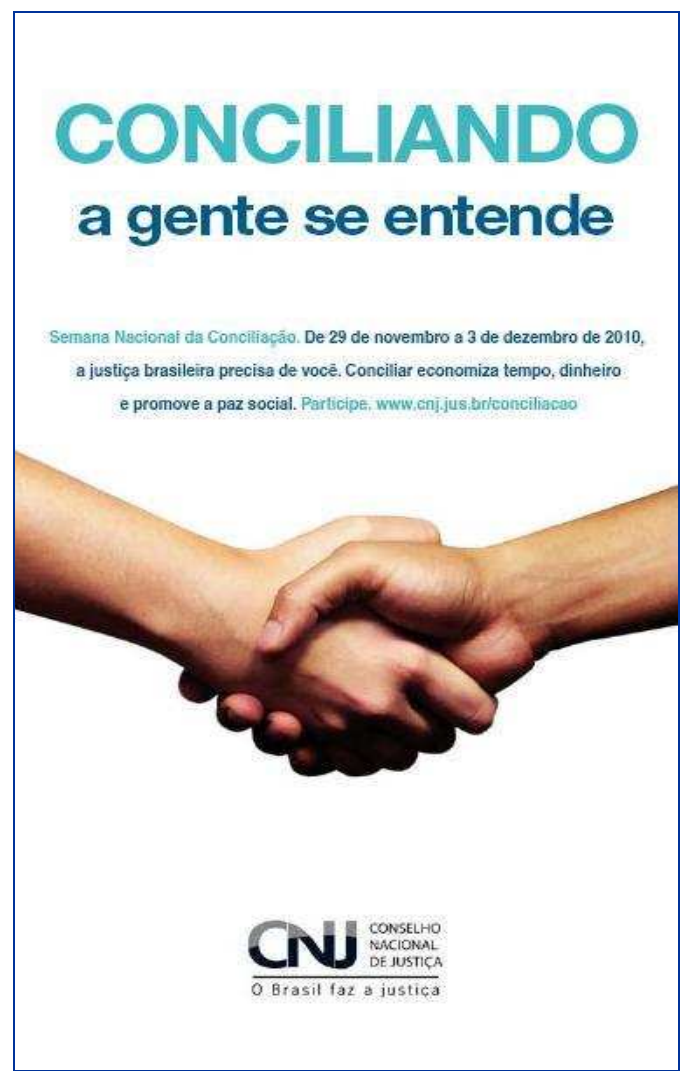

Fonte: Conselho Nacional de Justiça, 2011

Diferentemente da campanha do Programa Começar de Novo, que foca questões sociais relacionadas à ressocialização do ex-preso, a campanha do Movimento pela Conciliação demonstra preocupação mais específica com aspectos operacionais da justiça e tem objetivo claro de diminuir a quantidade de processos que dão entrada nos tribunais de justiça em todo o país. Desse modo, é promovida uma forma alternativa de resolver conflitos na justiça. Para o $\mathrm{CNJ}$ o litígio é ruim não só para o cidadão como também para o Judiciário e, consequentemente, para o país. Nesse sentido, as campanhas tiveram como foco mostrar que todos ganham com a conciliação; o principal público-alvo eram as partes em conflito, principais beneficiárias dos resultados rápidos da conciliação.

\section{Campanha pela Meta 2}

Mesmo sendo classificada pelo CNJ como uma campanha ligada à Meta 2 (identificação dos processos judiciais mais antigos e a adoção de medidas concretas para o julgamento de todos os distribuídos até 31 de dezembro de 2005), não foi possível diferenciar a peça dessa campanha (Figura 6) daquelas desenvolvidas para o Movimento pela Conciliação. Observou-se que a campanha também buscava promover o acordo entre as partes, justificando essa opção como melhor e mais rápida. 
Figura 6

\section{Peça publicitária da Campanha pela Meta 2}

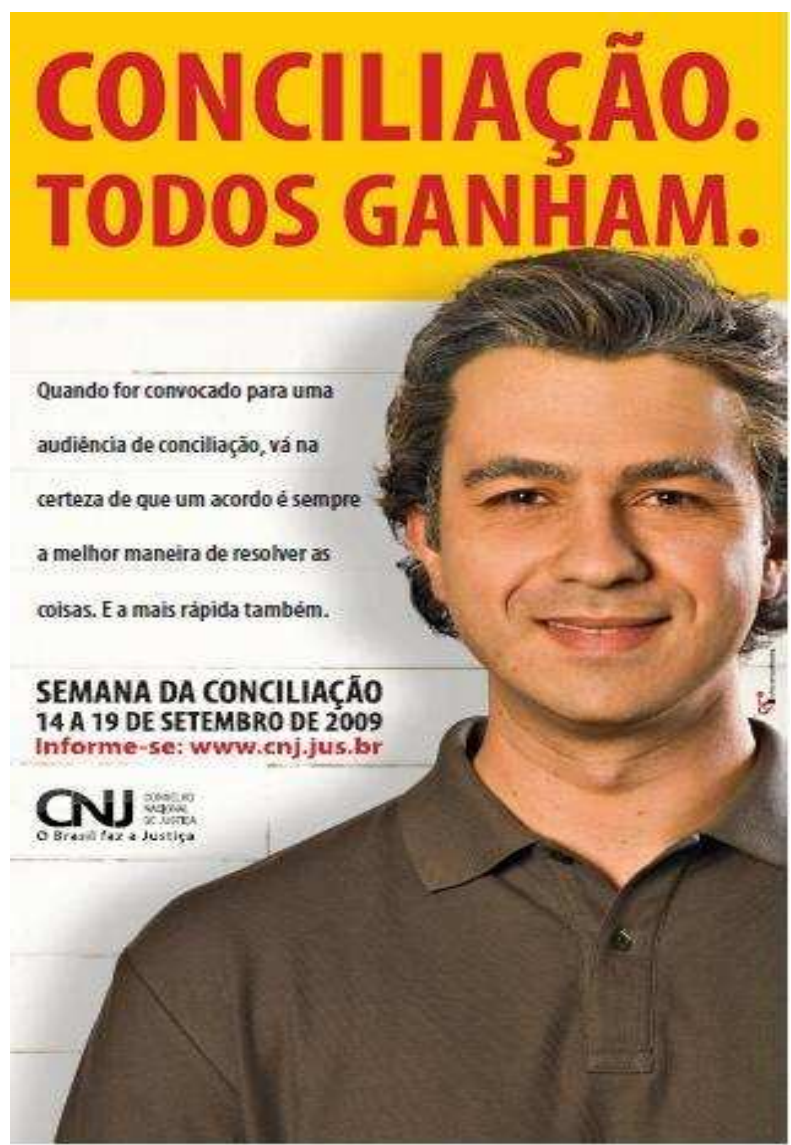

Fonte: Conselho Nacional de Justiça, 2011

A função de mostração apresenta-se no segundo nível de texto com a explicitação das intenções do projeto e a informação sobre a semana da conciliação. A interação apresenta-se nos três níveis de texto com expressões assertivas como "Conciliação. Todos ganham.”, "[...] vá na certeza de que um acordo é sempre a melhor maneira de resolver as coisas" e com a menção de que a conciliação é considerada como forma mais rápida de justiça. O convite à adesão por parte da sociedade ao movimento está sempre presente na campanha, representado pela função de interação. Assim como nas campanhas pela conciliação, a sedução aparece na maioria dos níveis de texto evocando afetos positivos: melhor, mais rápido. Os apelos textuais são complementados pelo conteúdo imagético: a expressão "[...] é sempre a melhor maneira de resolver as coisas e a mais rápida" é complementada pelo sorriso do homem demonstrando satisfação (função de sedução).

Evidencia-se, nessa campanha, a preocupação do CNJ com aspectos puramente operacionais da entrega de prestação jurisdicional, sem outra preocupação de caráter social. A origem da campanha, uma meta estabelecida pelo CNJ, serve como justificativa direta para esse posicionamento, e a conciliação seria o instrumento operacional de alcance dessa meta.

\section{Justiça Criminal}

A campanha Justiça Criminal visava ampliar o debate sobre segurança, com foco em penas alternativas, como forma de "punir melhor" o infrator em benefício da sociedade. Observando o texto da peça publicitária 
apresentada na Figura 7, a função de mostração faz-se presente no texto por meio da informação ao receptor sobre estatísticas relacionadas à aplicação de penas alternativas, da apresentação da proposta de discussão a respeito de tais penas, e da descrição das intenções do $\mathrm{CNJ}$ em relação à campanha de modernização da justiça criminal. A imagem de um homem que sugere a figura de um detento reforça a estratégia de apresentação da peça. A função de interação aparece nas frases assertivas, "A solução não é punir menos, é punir melhor", e em perguntas como: "O infrator que comete um crime grave deve ser punido com prisão. Mas será que todo crime é igual?" Dessa forma, a peça provoca o receptor a se posicionar diante do problema. A função de sedução está presente em palavras como "punir", "crime", "infrator" (afetos negativos) e "justiça", "melhor para todos" (afetos positivos), além da imagem do detento (afeto negativo).

\section{Figura 7}

\section{Peça publicitária da Campanha Justiça Criminal}

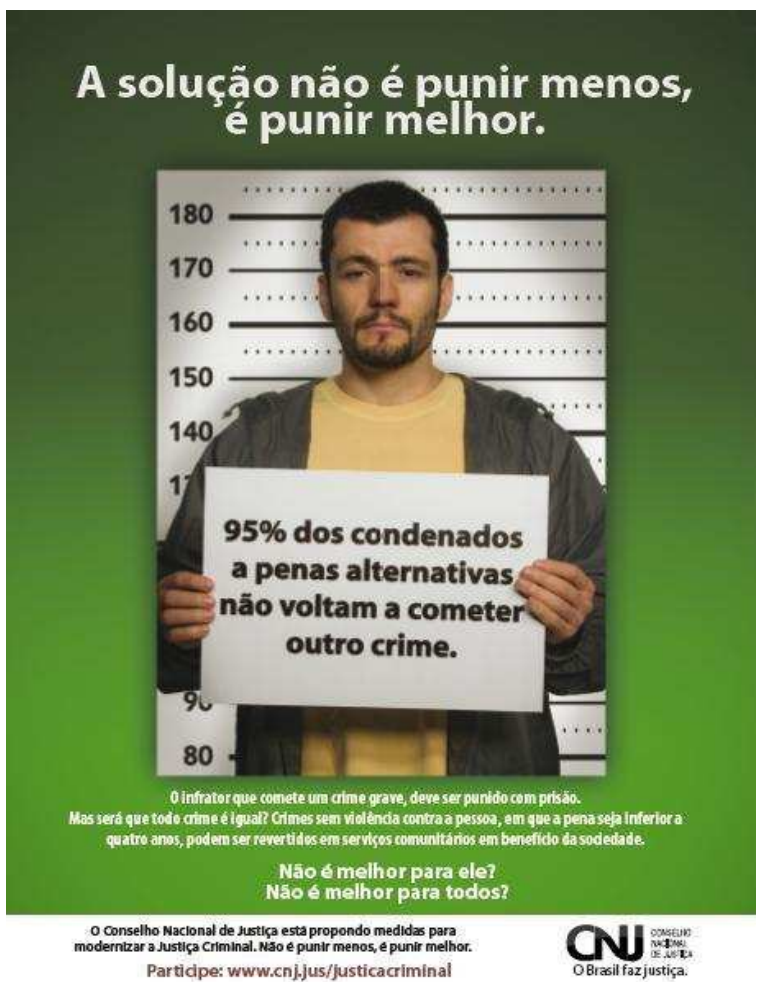

Fonte: Conselho Nacional de Justiça, 2011.

Discutir o tratamento ao infrator é algo que não costuma ser associado ao Poder Judiciário, que se manteve distante dessa questão por considerá-la responsabilidade do Executivo. Essa preocupação não parece ter relação mais direta com a forma como são realizadas as operações de prestação jurisdicional na justiça criminal. O único impacto sobre as operações estaria ainda em uma dimensão muito distante, na perspectiva de que condenados a penas alternativas apresentam menor propensão a voltar ao crime e, portanto, não voltariam a gerar demanda para o Judiciário. Observa-se em primeiro plano a preocupação social, bem como a perspectiva da campanha em gerar benefício para a sociedade com a modernização da justiça criminal.

\section{Campanha pela Lei Maria da Penha}

No segundo semestre de 2010, o CNJ desenvolveu campanha publicitária nacional com o objetivo de promover a aplicabilidade da Lei Maria da Penha tanto por parte dos órgãos judiciários como pela sociedade. 
A Lei Maria da Penha visa prevenir, punir e erradicar a violência contra a mulher. Nessa campanha, texto e imagem se complementam com o nome Maria da Penha escrito na cor rosa. A frase "Violência contra a Mulher não tem desculpa, tem Lei" pode ser representada pela flor, significando a fragilidade da mulher.

Figura 9

Peça publicitária da campanha pela Lei Maria da Penha - 2010

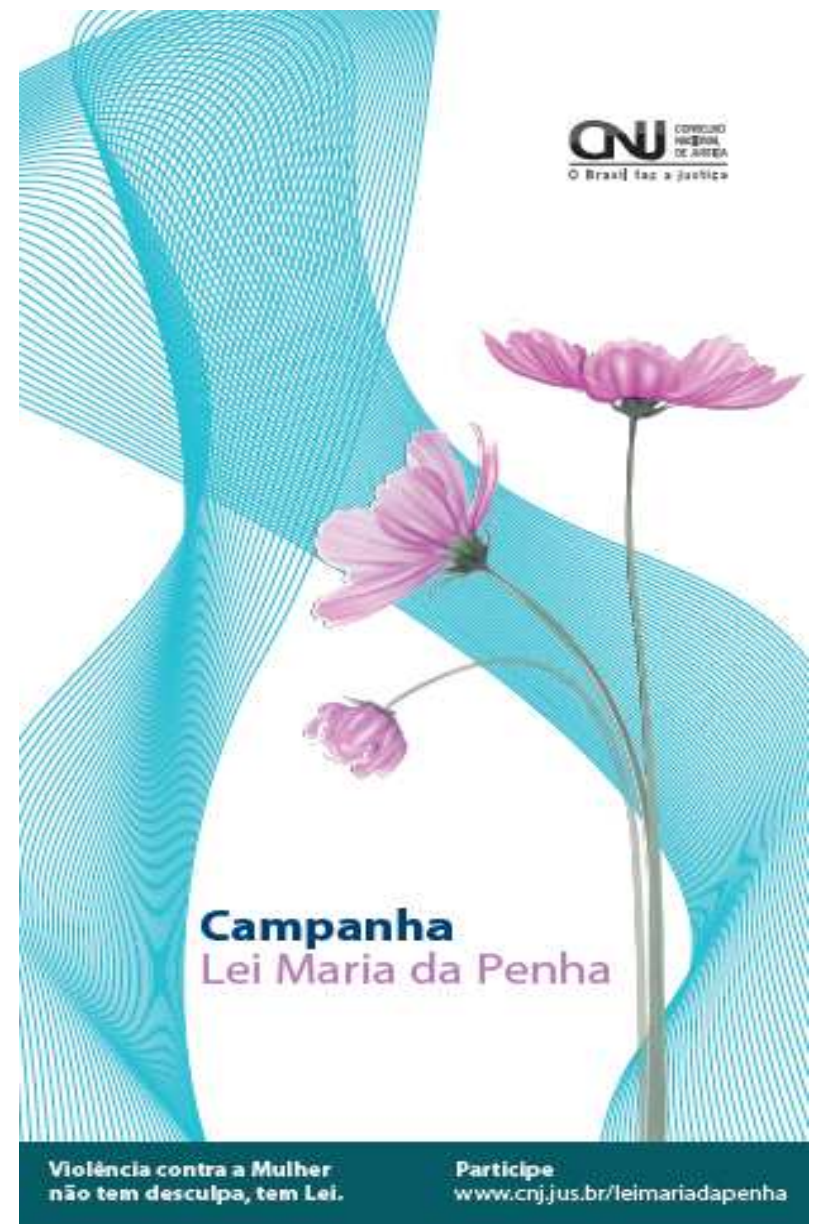

Fonte: Conselho Nacional de Justiça, 2011.

A mostração apresenta-se no texto pela explicitação da punição a quem realizar ato violento contra a mulher em ambiente doméstico, além das imagens utilizadas, que fazem referência ao universo feminino, com curvas e flores desenhadas em cores suaves (rosa e verde). A função de interação apresenta-se na frase imperativa "Violência contra a Mulher não tem desculpa, tem Lei" e na grafia da palavra "Mulher", iniciada com letra maiúscula para dar ênfase ao direcionamento da propaganda à mulher, e, também, na convocação à sociedade a participar e a denunciar a violência doméstica. As cores auxiliam a construção de identificação com o universo feminino. A função de sedução também está expressa em "Violência contra a mulher não tem desculpa, tem lei', que distribui afetos positivos e negativos, marca pessoas e acontecimentos, bem como na representação da mulher pela flor, que distribui afetos positivos ao se relacionar com a imagem de algo belo, delicado e frágil.

Nota-se que a preocupação do CNJ nessa campanha tem o caráter eminentemente social de conscientizar a população, principalmente a feminina, de seus direitos. O objetivo é divulgar uma lei que protege um grupo 
de pessoas que vem sendo alvo de violência doméstica e que passou a contar com apoio específico por parte do Judiciário. Não se observa uma preocupação operacional do CNJ nessa campanha.

\section{Categorização das Campanhas do CNJ}

Ao se iniciar um processo de reforma organizacional em que há necessidade de apoio de todas as camadas da sociedade, os processos de comunicação e posicionamento institucional dessa organização ganham importância elevada. Mais recentemente, tornou-se evidente a preocupação da administração pública com temas até pouco tempo desprezados, como a comunicação e a construção da imagem institucional.

A observação das peças das campanhas do CNJ permitiu constatar que dentro das atribuições de planejamento e publicidade do Poder Judiciário, o órgão tomou a frente do processo de reconstrução da imagem deste poder. Mesmo que as campanhas desenvolvidas no período de 2008 a 2010 estejam voltadas exclusivamente para o público externo do Judiciário, percebe-se a ampla abrangência da atuação do órgão na tentativa de mudar a forma como o Judiciário é visto pela sociedade.

Em suas campanhas, o CNJ mostrou disposição em tratar de questões polêmicas dentro e fora do Poder Judiciário. A ressocialização do ex-detento e sua reincorporação ao mercado de trabalho, a violência doméstica e a aplicação de penas alternativas, por exemplo, ainda geram discussão em nosso país. Não obstante, o CNJ mostra que deseja liderar o debate em torno desses temas. Isso demonstra uma nova forma de o Poder Judiciário relacionar-se com a sociedade e a importância conferida a campanhas de comunicação institucional.

Analisando o discurso publicitário das peças lançadas pelo CNJ, foi possível distinguir duas categorias: discurso social e discurso operacional. As campanhas do Programa Começar de Novo; Justiça Criminal; e Lei Maria da Penha mostram o interesse do CNJ em colocar à disposição da sociedade as funções sociais da prestação jurisdicional. Essas campanhas apresentam em primeiro plano as melhorias sociais que podem ser promovidas pelo Poder Judiciário e tratam de ampliação da cidadania, diminuição da criminalidade, aumento da equidade e do sentimento de justiça. Ao fim, o que essas campanhas transmitem ao público é o interesse do CNJ em promover a paz social. São vistas nessas campanhas as figuras de indivíduos situados em um espaço social limítrofe entre o crime e a vida honesta (Programa Começar de Novo e Justiça Criminal). Essas figuras marcam a importância das iniciativas da justiça para a melhora das condições sociais de todos e convoca a sociedade a se posicionar nessa discussão. De forma diferente, mas ainda assim alinhada à perspectiva de mudança social, a campanha da Lei Maria da Penha trata abertamente do combate à violência contra a mulher, utiliza flores como conteúdo imagético que promove o entendimento da mensagem e reforça a necessidade de engajamento da sociedade.

Do ponto de vista do discurso voltado para a operação do Judiciário, as campanhas pela Conciliação e pela Meta 2 tratam mais especificamente de questões importantes para o processo de prestação jurisdicional, mas não de seu resultado. Mesmo apresentando um discurso que se aproxima da questão social ao evocar o entendimento entre as partes, ambas as campanhas estão centradas na perspectiva de se ampliar a possibilidade de resolução de conflitos com base nos mecanismos de conciliações judiciais. As conciliações podem acelerar o resultado da prestação jurisdicional e, por consequência, tornar mais célere o Poder Judiciário. Assim, o Judiciário é apresentado como solucionador mais eficiente dos conflitos entre as partes, o que contribuiria para a construção de uma nova e positiva imagem institucional.

O Quadro 2, a seguir, localiza dentro das categorias propostas cada uma das peças de campanhas publicitárias lançadas pelo CNJ entre 2008 e 2010 de acordo com o discurso publicitário proposto (social ou operacional) e a forma de ação proposta pelo órgão. O Quadro 3 traz a matriz analítica das peças publicitárias utilizadas na pesquisa. 
Quadro 2

\section{Categorização das campanhas do CNJ}

\begin{tabular}{|c|c|c|}
\hline Campanha & $\begin{array}{c}\text { Categoria do Discurso } \\
\text { Publicitário }\end{array}$ & Forma de ação do discurso \\
\hline Programa Começar de Novo -2008 & Social & Ressocialização do ex-detento. \\
\hline Programa Começar de Novo -2009 & Social & Ressocialização do ex-detento. \\
\hline Movimento pela Conciliação -2008 & Operacional & Conciliação e entendimento. \\
\hline Movimento pela Conciliação -2009 & Operacional & Conciliação e entendimento. \\
\hline Movimento pela Conciliação -2010 & Operacional & Conciliação e entendimento. \\
\hline Meta 2-2009 & Operacional & Conciliação e entendimento. \\
\hline Justiça Criminal - 2010 & Social & Defesa de penas alternativas. \\
\hline Lei Maria da Penha - 2010 & Social & Sensibilização e valorização da mulher. \\
\hline
\end{tabular}

Fonte: Elaborado pelos autores.

Quadro 3

Matriz analítica das peças publicitárias utilizadas na pesquisa

\begin{tabular}{|c|c|c|c|c|}
\hline $\begin{array}{c}\text { Campanha / } \\
\text { Peça }\end{array}$ & Universo & Mostração & Interação & Sedução \\
\hline \multirow{2}{*}{$\begin{array}{c}\text { Começar de } \\
\text { Novo }-2008 \text { e } \\
2009\end{array}$} & Texto & $\begin{array}{l}\text { CNJ como patrocinador } \\
\text { do projeto (campanha } \\
\text { de 2008); } \\
\text { ressocialização pelo } \\
\text { trabalho; } \\
\text { trabalho como antítese } \\
\text { do crime. }\end{array}$ & $\begin{array}{l}\text { Busca por apoio da } \\
\text { sociedade. }\end{array}$ & $\begin{array}{l}\text { Afetos negativos (errar, } \\
\text { ignorar) e positivos } \\
\text { (recomeçar, ajudar, } \\
\text { humanidade } \\
\text { liberdade). }\end{array}$ \\
\hline & Imagem & $\begin{array}{l}\text { CTPS e régua (trabalho } \\
\text { e crime - campanha de } \\
\text { 2008); bola de ferro e } \\
\text { flor (erro e recomeço - } \\
\text { campanha de 2008); } \\
\text { faces (clara e escura - } \\
\text { campanha de 2009). }\end{array}$ & $\begin{array}{l}\text { Olhar (vitória, } \\
\text { reconhecimento do } \\
\text { papel do homem } \\
\text { como provedor, } \\
\text { contato direto com o } \\
\text { receptor). }\end{array}$ & $\begin{array}{l}\text { Afetos negativos } \\
\text { (crime, erro, bola de } \\
\text { ferro) e positivos } \\
\text { (orgulho, satisfação, } \\
\text { beleza). }\end{array}$ \\
\hline
\end{tabular}


Continuação do Quadro 3

\begin{tabular}{|c|c|c|c|c|}
\hline $\begin{array}{c}\text { Campanha / } \\
\text { Peça }\end{array}$ & Universo & Mostração & Interação & Sedução \\
\hline \multirow{2}{*}{$\begin{array}{l}\text { Movimento } \\
\quad \text { Pela } \\
\text { Conciliação - } \\
\text { 2008, } 2009 \text { e } \\
2010\end{array}$} & Texto & $\begin{array}{l}\text { Conciliação como } \\
\text { forma de resolução de } \\
\text { conflitos (campanha } \\
\text { 2008); mudança na } \\
\text { justiça (campanha de } \\
\text { 2009); pacificação } \\
\text { social e entendimento } \\
\text { (campanha de 2010). }\end{array}$ & $\begin{array}{l}\text { Justiça aberta à } \\
\text { sociedade; busca por } \\
\text { participação da } \\
\text { sociedade; economia } \\
\text { de tempo e dinheiro } \\
\text { (campanha de 2010). }\end{array}$ & $\begin{array}{l}\text { Afetos positivos } \\
\text { (conciliação é rápida, } \\
\text { simples e legal: } \\
\text { campanha de 2008; } \\
\text { conciliação traz ganhos } \\
\text { para todos: campanha } \\
\text { de 2009; conciliação } \\
\text { como um aperto de } \\
\text { mão: campanha de } \\
\text { 2010). }\end{array}$ \\
\hline & Imagem & $\begin{array}{l}\text { Descrição visual simples } \\
\text { de uma sessão de } \\
\text { conciliação; aperto de } \\
\text { mãos (campanha de } \\
\text { 2008); cores verde e } \\
\text { amarelo e letras } \\
\text { grandes (campanha de } \\
\text { 2009); aperto de mãos } \\
\text { (campanha de 2010). }\end{array}$ & $\begin{array}{l}\text { Cores nacionais } \\
\text { (campanha de 2009); } \\
\text { aperto de mãos como } \\
\text { processo de interação } \\
\text { entre as partes } \\
\text { (campanha de 2010). }\end{array}$ & $\begin{array}{c}\text { Afetos positivos } \\
\text { (situação amistosa e } \\
\text { harmoniosa: campanha } \\
\text { de 2008; patriotismo: } \\
\text { campanha de 2009; } \\
\text { união, acordo e paz: } \\
\text { campanha de 2010). }\end{array}$ \\
\hline \multirow[b]{2}{*}{ Meta 2 - 2009} & Texto & $\begin{array}{l}\text { Informação a respeito } \\
\text { da semana de } \\
\text { conciliação. }\end{array}$ & $\begin{array}{l}\text { Ganhos para todos } \\
\text { com a conciliação; } \\
\text { convocação da } \\
\text { sociedade. }\end{array}$ & $\begin{array}{l}\text { Afetos positivos } \\
\text { (rapidez e ganho). }\end{array}$ \\
\hline & Imagem & $\begin{array}{c}\text { Indivíduo "como nós", } \\
\text { que significa relação } \\
\text { com problema comum } \\
\text { a todos. }\end{array}$ & $\begin{array}{l}\text { Sorriso e olhar que } \\
\text { buscam interagir com } \\
\text { o receptor. }\end{array}$ & $\begin{array}{l}\text { Afetos negativos } \\
\text { (cabelo grisalho } \\
\text { relacionado à demora } \\
\text { na solução de conflitos, } \\
\text { longa espera) e } \\
\text { positivos (sorriso } \\
\text { resultante de acordo } \\
\text { via conciliação). }\end{array}$ \\
\hline \multirow[t]{2}{*}{$\begin{array}{l}\text { Justiça Criminal } \\
-2010\end{array}$} & Texto & $\begin{array}{c}\text { Estatísticas } \\
\text { relacionadas à } \\
\text { aplicação de penas } \\
\text { alternativas; discussão } \\
\text { a respeito do uso de } \\
\text { penas alternativas; } \\
\text { intenção do CNJ de } \\
\text { modernizar a justiça } \\
\text { criminal. }\end{array}$ & $\begin{array}{l}\text { Discussão a respeito } \\
\text { da punição; } \\
\text { convocação da } \\
\text { sociedade para a } \\
\text { discussão. }\end{array}$ & $\begin{array}{c}\text { Afetos negativos } \\
\text { (punição, crimes e } \\
\text { infratores) positivos } \\
\text { (justiça, o que é melhor } \\
\text { para todos). }\end{array}$ \\
\hline & Imagem & $\begin{array}{l}\text { Descrição da imagem } \\
\text { de um detento, régua, } \\
\text { placa com dados } \\
\text { estatísticos (trabalho e } \\
\text { crime). }\end{array}$ & $\begin{array}{l}\text { Olhar fixo do homem } \\
\text { que provoca } \\
\text { interação com o } \\
\text { receptor. }\end{array}$ & $\begin{array}{l}\text { Afetos negativos } \\
\text { (semblante do homem, } \\
\text { imagem de detento). }\end{array}$ \\
\hline
\end{tabular}


Continuação do Quadro 3

\begin{tabular}{|c|c|c|c|c|}
\hline $\begin{array}{c}\text { Campanha / } \\
\text { Peça }\end{array}$ & Universo & Mostração & Interação & Sedução \\
\hline \multirow{2}{*}{$\begin{array}{c}\text { Lei Maria Da } \\
\text { Penha - 2010 }\end{array}$} & Texto & $\begin{array}{c}\text { Punição a atos } \\
\text { violentos contra } \\
\text { mulheres. }\end{array}$ & $\begin{array}{c}\text { Empatia com as } \\
\text { mulheres; } \\
\text { participação da } \\
\text { sociedade. }\end{array}$ & $\begin{array}{c}\text { Afetos negativos } \\
\text { (violência contra } \\
\text { mulher) e positivos (lei } \\
\text { que trata desse tipo de } \\
\text { crime). }\end{array}$ \\
\cline { 2 - 5 } & Imagem & $\begin{array}{c}\text { Universo feminino } \\
\text { (curvas e flores); cores } \\
\text { suaves. }\end{array}$ & Cores femininas. & $\begin{array}{c}\text { Afetos positivos } \\
\text { (beleza, delicadeza, } \\
\text { fragilidade). }\end{array}$ \\
\hline
\end{tabular}

Fonte: Elaborado pelos autores.

\section{Considerações Finais}

O movimento de reforma do Estado brasileiro chegou ao Poder Judiciário no final de 2004 e trouxe mudanças significativas em sua estrutura e forma de gestão, entre elas a criação do CNJ. Este órgão proporcionou ao Judiciário a construção de um espaço de reflexão a respeito de suas práticas e de orientação institucional e se tornou responsável pela condução de ações de comunicação com os públicos do Judiciário.

A condução do processo de mudanças na gestão do Judiciário e na construção da imagem institucional levou o CNJ a promover a veiculação de cinco campanhas publicitárias (compostas de oito peças no total) no período entre 2008 e 2010. O simples movimento de lançamento de campanhas publicitárias já pode ser entendido como uma mudança no comportamento do Judiciário, normalmente associado a uma posição passiva, de poder que precisa ser provocado.

A análise das peças publicitárias oficiais do CNJ evidenciou a intenção de reposicionamento institucional por parte do Judiciário. Foi possível identificar em todas as campanhas sua determinação em expor uma preocupação em relação a mais transparência de suas ações e à oferta de prestação de serviços jurisdicionais mais céleres como forma de se ampliar a paz social e dar suporte à cidadania. Dessa forma, o Judiciário mostra-se mais aberto e próximo da sociedade e a convoca a participar e contribuir para o alcance dos objetivos de sua reforma.

Foi possível perceber duas categorias distintas de discursos publicitários utilizados nas peças lançadas pelo CNJ. As que compõem a primeira categoria são caracterizadas pela presença de discussão de questões sociais. O discurso publicitário dessas peças é menos dedicado à discussão da operação do Judiciário e mais preocupado com a discussão de temas que envolvem a justiça e têm elevada relevância para a sociedade. Tal discurso foi encontrado nas campanhas do Programa Começar de Novo, Justiça Criminal e Lei Maria da Penha. A intenção do CNJ nesses casos era apresentar o Poder Judiciário como condutor dessas discussões na sociedade.

A segunda categoria de discurso publicitário foi denominada de discurso operacional. Tal discurso está centrado na ideia de promoção de processos de prestação de serviços jurisdicionais mais rápidos. Essa perspectiva está relacionada à proposta de aumento da celeridade e diminuição dos estoques de processos que continuam crescendo em todos os tribunais do país. As campanhas pela Conciliação e pela Meta 2 têm a proposta clara de apresentar à sociedade um procedimento judicial alternativo que pode oferecer uma solução mais rápida. Tal preocupação também é legítima ao Poder Judiciário e reforça a ideia de seu novo posicionamento institucional. 
Observou-se que as ações de comunicação lançadas pelo CNJ têm como objetivo transformar a imagem do Poder Judiciário, que sempre esteve relacionada a morosidade, punição, prisão, na imagem de um poder voltado para equidade, justiça, proteção da mulher, liberdade e ressocialização. Dessa forma, o Judiciário passa a estabelecer vínculos com a sociedade por meio de ações de comunicação e, com isso, o alinhamento de um horizonte comum entre o Judiciário e o cidadão. Dada a importância que o Poder Judiciário tem para o Estado brasileiro, espera-se que mais pesquisas tratem de temas relacionados a este poder, incluindo suas estratégias de comunicação.

\section{Referências}

ABRUCIO, F. L. Os avanços e os dilemas do modelo pós-burocrático: a reforma da administração pública à luz da experiência internacional recente. In: BRESSER PEREIRA, L. C.; SPINK, P. K. (Eds.). Reforma do Estado e administração pública gerencial. Rio de Janeiro: FGV, 1998. p.173-199.

BADIN, L. A. O Conselho Nacional de Justiça: pedra angular da reforma constitucional do Poder Judiciário. Revista Brasileira de Estudos Constitucionais, v. 3, n. 9, p. 27-39, jan./mar., 2009.

BALMER, J. M. T. Corporate marketing: apocalypse, advent and epiphany. Management Decision, v. 47, n. 4, p. 544$572,2009$.

BRESSER PEREIRA, L. C. Da administração burocrática à gerencial. Revista do Serviço Público, v. 47, n. 1, p. 5-33, jan./abr., 1996.

2000.

A Reforma gerencial do Estado de 1995. Revista de Administração Pública, v. 34, n. 4, p. 7-26, jul./ago.,

Uma nova gestão para um novo Estado: liberal, social e republicano. Revista do Serviço Público, v. 52, n. 1, p.5-24, jan./abr., 2001.

CARVALHO, N. M. O discurso publicitário. Comunicação: Veredas, v. 3, n. 3, p. 207-222 nov. 2004.

Publicidade: a linguagem da sedução. 3. ed. São Paulo: Ática, 2009.

CHAER, A. C. L.; AZEVEDO J. S. F.; BONIFÁCIO I. G. Projeto de gestão estratégica do Poder Judiciário do Brasil. In: II CONGRESSO CONSAD DE GESTÃO PÚBLICA. 2. Brasília, 2009. Anais... Brasília: CONSAD, 2009.

CONSElHO NACIONAL DE JUSTIÇA. Departamento de Pesquisas Judiciárias, Brasília (DF), 2011.

DINIZ, E. Globalização, reforma do Estado e teoria democrática contemporânea. São Paulo em Perspectiva, v. 15, n. 4, p.13-22, out./dez., 2002.

DYER, R. F.; SHIMP, T. A. Enhacing the role of marketing research in Public Policy decision making. Journal of Marketing, v. 41, Jan., p. 63-67, 1977.

EWING, M. T.; CARUANA, A. An internal marketing approach to Public Sector management: The marketing and human resources interface. The International Journal of Public Sector Management, v. 12, n. 1, p.17-26, 1999.

KOTLER, P. A generic concept of marketing. Journal of Marketing, v. 36, p. 46-54, 1972.

Administração de marketing. 12. ed. São Paulo: Prentice Hall, 2000.

Marketing no setor público. Porto Alegre: Bookman, 2008.

; LEVY, S. J. Broadening the concept of Marketing. Journal of Marketing, v. 33, Jan., p. 10-15, 1969. 
LAING, A. Marketing in the public sector: towards a typology of public services. Marketing Theory, v. 3, n. 4, p. 427445, 2003.

LUCK, D. J. Broadening the concept of Marketing - too far. Journal of Marketing, v. 33, June, p. 53-55, 1969.

NALINI, R. A Rebelião da Toga. Campinas: Millennium, 2006.

PINTO, M. J. Comunicação e discurso. 2. ed. São Paulo: Hacker, 2002.

POYARES, W. Imagem pública: glória para uns, ruína para outros. 2. ed. São Paulo: Ed. Globo, 1998.

REZENDE, F. C. Por que falham as reformas administrativas? Rio de Janeiro: FGV, 2004.

RIBEIRO, L. A Emenda Constitucional 45 e a questão do acesso à justiça. Revista Direito GV, v. 4, n. 2, p. 465- 492 , 2008.

SADEK, M. T. Judiciário: mudanças e reformas. Estudos Avançados, v. 18, n. 51, p. 79-101, 2004.

Acesso à Justiça: visão da sociedade. Justitia, v. 1, p. 271-280, 2009.

TAVARES, F. Publicidade e consumo: a perspectiva discursiva. Revista Comum, v. 11, n. 26, p. 117-144, 2006.

VIEIRA, J. L. M.; PINHEIRO, I. A. Contribuições do Conselho Nacional de Justiça para a gestão do Poder Judiciário. In: ENCONTRO DA ANPAD, 32, Rio de Janeiro, 2008. Anais... Rio de Janeiro: ANPAD, 2008.

WALSH, K. Marketing and Public Sector Management. European Journal of Marketing, v. 28, n. 3, p. 63-71, 1994.

WILKIE, W. L.; GARDNER, D. M. The role of Marketing research in Public Policy decision making. Journal of Marketing, v. 38, Jan., p. 38-47, 1974. 